This is a postprint (final submitted manuscript) version of the following article:

Parris, D., \& McInnis-Bowers, C. (2014). Social entrepreneurship questioning the status quo: Waste as a resource. Journal of Economic Issues, 48(2), 359-366.

https://doi.org/10.2753/JEI0021-3624480209 


\title{
Social Entrepreneurship Questioning the Status Quo. Waste as a Resource
}

\section{Denise L. Parris and Cecilia V. Mdnnis-Bowers}

Denise L. Parris is a visiting assistant professor and Cecilia V. McInnis-Bowers is a professor both in the Department of Business and Social Entrepreneurship at Rollins College, FL.

\begin{abstract}
There has been an increasing interest in social entrepreneurs' roles in creating social value, fostering economic development, and advancing environmental sustainability. In institutional economics, there is extensive support for entrepreneurship as having a positive impact on economic development and personal wellbeing. This paper challenges the accepted understanding of social entrepreneurs as being "heroic" and their process of starting a new venture as beginning with passion or with the recognition of a social problem. Through examining the case of Clean the World, a social enterprise, we demonstrate that not all social ventures start with the intention of creating social value, but with the question: How can I make a profit? We discuss a recently proposed paradigm called effectual entrepreneurship, and then we illustrate how this paradigm fits the path of Clean the World. Effectual entrepreneurs questioned the status quo and focused on the existing or available resources, rather than on identifying opportunities first. We then explore how Clean the World fell into social entrepreneurship by "accident" while considering waste a resource. We conclude by making some suggestions about how to facilitate more of these "accidents" by fostering a culture that questions the status quo.
\end{abstract}

Keywords. causation process, development, effectual process, environmental sustainability, social entrepreneurship, social value

\section{JEL Classification Codes: L26, O10, Q56}

By questioning the status quo, an entrepreneur either identifies or creates market possibilities (Gaglio and Katz 2001; Kirzner 1973, 1999; Sarasvathy 2001; Schumpeter 1934, 1943). Entrepreneurship is understood in institutional economics as playing an essential role in advancing economic development and human wellbeing (Gimmon and Levie 2009; Klein 1988; McDaniel 2003, 2005; Warnecke 2013). There has been a growing interest in social entrepreneurs who seek to promote social value, economic development, and environmental sustainability (Mair and Mati 2006; Warnecke 2013). The interplay between growth, the environment, and development has been heavily discussed in institutional economics (van den Bergh and Kallis 2012). Much of the social entrepreneurship literature portrays the process of social entrepreneurship as starting with the passion for or from the recognition of a social problem (Dacin, Dacin and Tracey 2013). An attribute often ascribed to the social entrepreneur is that of a "hero" who eschews self-interest.

We challenge this accepted understanding of the nature and process of social entrepreneurship through examining Clean the World, a social enterprise. This paper starts by discussing a recently 
proposed entrepreneurial paradigm called effectual entrepreneurship (Saravarthy 2001). We then illustrate the fit of this paradigm to the path followed by Clean the World from two key perspectives: questioning the status quo and focusing on existing or available resources first before identifying opportunities. By examining the case of Clean the World, this paper demonstrates that not all social ventures start with the intention of creating social value; some start with asking: How can I make a profit? Furthermore, we explore how the new business model of Clean the World fell into social entrepreneurship by "accident," while recognizing waste a resource. We conclude with some suggestions about how to facilitate more of these "accidents" by fostering a culture that questions the status quo.

\section{A New Paradigm: Effectual Entrepreneurship}

Scholars have begun to distinguish between social and market entrepreneurship. Joseph Schumpeter's (1943) pioneering work on market entrepreneurship acknowledged the roles of personal qualities, such as boldness, imaginativeness, and creativity in enabling entrepreneurs to not operate passively in the world, but to disrupt the status quo by introducing previously unthought-of products, methods, and markets. Aligned with Schumpeter's creativity notion is the entrepreneurial quality of alertness introduced by Israel M. Kirzner $(1973,1999)$. An alert entrepreneur responds to existing possibilities, previously unseen, to create market opportunities (Kirzner 2009). Both the entrepreneurial process of identifying yet unrecognized possibilities and the creativity of generating opportunities result in the creation of new economic opportunities. The social entrepreneur's intentionality is to improve a social problem by building a sustainable for-profit or nonprofit venture to ensure the continuance of the organization's social mission.

The traditional paradigm of social entrepreneurship is that it starts with a given social problem and focuses on selecting between effective ways to positively impact the problem. The social entrepreneurial process is understood to be an ongoing and repetitive cycle of envisioning, formulating, taking action, evaluating, and sustaining (London 2008). Thus, the process follows the causation process of entrepreneurship starting with search for an opportunity, such as a solution for a market need or a new product that brings value to customers, followed by marshaling of resources (financial and otherwise), and culminating in the creation of a sustainable organization.

Saras Sarasvathy $(2001,245)$ defined the causation process to "take a particular effect as given and focus on selecting between means to create that effect." A causation process is underlined in economic theories contending that "artifacts such as firms are inevitable outcomes, given the preference ordering of economic actors and certain simple assumption of rationality (implying causal reasoning) in their choice behavior" (Sarasvathy 2001, 245). In the traditional entrepreneurial paradigm, the process of starting a new venture begins with multiple searches for new possibilities from a predetermined market, and continues with the identification of the "big idea," followed by selecting an optimal target segment from the market. The causation entrepreneur views the world as "static, linear, and independent environments" (Sarasvathy 2001, 251), and focuses on predictability of the future with outcomes to increase market share in existing markets through the execution of competitive strategies. Thus, operating from a causation framework by assuming the future is predictable - and, therefore, controllable - does not foster questioning the status quo.

Alternatively, the new effectual entrepreneurship paradigm begins the process of starting a new venture in the opposite direction of first exploring a set of means - or resources - available. 
The effectuation process is defined by taking "a set of means as given and focus on selecting between possible effects" (Sarasvathy 2001, 245). In a paradigm shift, the effectual entrepreneur views the world as having "dynamic, nonlinear, and ecological environments" (Sarasvathy 2001, 251), and focuses on some controllable aspects of the unpredictable future with the outcome of developing new markets through alliances and cooperative strategies. As a consequence, operating from an effectual framework assumes the future is emerging, whereas, the traditional causation framework assumes a predictable future that is static and linear. Thus the effectual framework encourages questioning the status quo.

In entrepreneurship literature, a new venture is either explored through the framework of causation or effectuation. We offer one of the first examples, through the case of Clean the World, of how entrepreneurs start the entrepreneurial process from a causation paradigm, and then switch to an effectual paradigm. In the case of Clean the World, this transformation came as a result of their recognizing that waste could be a resource given the opportunity.

\section{The Case of Clean the World}

In February 2009, John Seipler and Paul Till started Clean the World, a nonprofit, which has a twoprong mission: (i) collect and recycle soap and shampoo products discarded by the hospitality industry; and (ii) distribute these and other donated hygiene products to impoverished people to prevent millions of deaths caused hygiene-related illnesses every day (Clean the World 2013). The entrepreneurs did not intend to create a nonprofit, nor did they have any prior experience in this sector. Rather, they were looking for an opportunity to own a business which would surpass their already substantial income as partners in the e-commerce industry. Their intention was to take advantage of the political and business climate favoring environmental sustainability, and they wanted to own a "green" company with the goal of "mak[ing] a buck" (Santich 2012). They were responding to the upswing of liberal environmentalism, whose proponents echo the classical economist Adam Smith's belief that "a sustainable society can best be realized by way of market forces, alongside scientific progress and individual consumer choice” (Dale 2012, 860). At this stage, these entrepreneurs were using a causation paradigm as they looked for the next "big Green idea." Their decision-making criteria included (i) helping "choose a means to achieve the given effect" and (ii) "selection criteria ... based on expected return" (Sarasvathy 2001, 251). As they (Seipler and Till) were searching for the new, high-potential opportunity in 2008, while on a business trip, Seipler identified a previously unseen possibility in recycling soap discarded by the hotel industry.

Each day, one million bars of hotel soap are dumped in landfills in the United States (Braun and Glenn 2013). The identification of discarded soap as a potential resource from which to make a profit began to shift the partners' framework from a causation process to an effectuation process. Consequently, their decision-making criteria focused on helping "choose between possible effects that can be created with given means" and "selection criteria based on affordable loss or acceptable risk" (Sarasvathy 2001, 251). In contrast to exploiting the competencies of knowledge, applied in the causation process, they began to practice an effectual competency of exploiting contingencies. The partners started questioning the existing system with the intent of discovering how this discarded resource could be recycled, repurposed, and made valuable. More importantly, they wanted to know if it could be a business that made money? 
With no apparent market opportunity for recycled soap in the US, "the ick factor" of used soap could not be overcome (Santich 2012), and they searched to discover new contingencies. The United Nations Children's Fund (UNICEF) study indicated that 2.2 million people die every year because of hygiene-related illnesses. These are mostly children under five and sixty-five percent of those deaths could be prevented if the children had access to soap. This was the "aha moment" for Seipler and Till (Braun and Glenn 2013). The two top killers of children less than five-year old in thirdworld countries are acute respiratory infection and diarrheal diseases, and the impact of these fatal diseases can be significantly reduced by simple hand-washing (Clean the World 2013). This is where Seipler and Till found the opportunity to use discarded soap to transform global hygiene.

In discovering that the opportunity resided in the third world and amongst the poorest changed, the founders' orientation shifted from pursuit of profit to advancing the social mission of distributing recycled soap. At this phase of the effectual entrepreneurship process by "accident," these partners became social entrepreneurs. This reorientation of their intention from seeking profit to advancing a social mission lead to a cascade of decisions. First, to move soap from hotels in the first world to the third would require a different kind of business model. Second, the value proposition - an innovation, service or feature intended to appeal to a customer's decision-making drivers - would need to be compelling for hotels to participate and to change their existing system of discarding the soap. Third, a distribution system would need to get the soap to Clean the World for processing and then sent it across the world, largely into areas that lack developed infrastructures.

Accordingly, the business model needed to address two actors: hotel management and people in the third world who need the soap. Hotel management is currently under the pressure from the sustainability movement to document how they are going "Green," in addition to the pressure to make profit. The value proposition for hotel management to partner with Clean the World was threefold: (i) reducing the tonnage sent to landfills; (ii) improving the health of people in the third world; and (iii) decreasing the cost of the hotels' throughput. No significant changes or additional time would be required of the house-keeping staff and the fee paid to Clean the World would be less than the fee paid to the landfills. Presently, Clean the World tracks the tonnage of soap that would have otherwise gone to landfills for each participating hotel and provides data for the participating hotels' sustainability reports. In addition, the organization produces public relations materials for display in hotel rooms and lobbies to inform hotel guests of their commitment and impact on environmental sustainably and on saving the lives of children globally. As a consequence, hotels are able to promote their corporate citizenship to clients, while also saving money. The business was a win for the hotels.

Distributing soap throughout the third world was accomplished, first, by organizing distribution trips to Haiti in 2009, with 2,000 bars of soap being delivered to the 48th least developed country in the world (Clean the World 2013). Although mission-centred and motivated to see an impact first hand, inefficiencies and scalability in reaching more people across the globe became issues for Clean the World. By identifying a value proposition for non-governmental organizations (NGOs), Clean the World has been able to align with strategic partners who have expertise in distribution of goods in the third world. NGOs buy soap to put into the hygiene kits they distribute. The value proposition was to provide the soap to NGOs at a substantial ninety percent reduction in cost (Till 2013). Effectual social entrepreneurs capitalized on two opportunities to meet the needs of both key actors - the hotel industry in the first world and NGOs in the third world. The effort to satisfy these needs resulted in a sustainable economic engine that covers roughly fifty percent of the expenses of the 
Clean the World, with the remainder coming from grants and donations (Clean the World 2013). Clean the World scaled the social mission impact via strategic partnership with NGOs. And they scaled throughput by opening soap recycling centers in geographically strategic areas located near major tourist-hospitality hubs. Over eleven million bars of soap have been distributed to people in need (Santich 2012; Clean the World 2013).

Clean the World provides insight into a new business model and the role of the effectual entrepreneur process in challenging the status quo. Even though these entrepreneurs' original framework was a causation process, with the self-interested intent of creating a new "Green" venture to make money, their paradigm was eventually transformed into an effectual entrepreneurial process whereby they used waste as a resource to generate profit. As they searched for contingencies, the founders identified their first profit- and social-value opportunity: discarded soap for less from the hotel industry and, as a consequence, less waste in landfills. As they questioned the status quo by further exploiting contingences, while also seeking cooperative strategies, Clean the World identified their second profit- and social-value opportunity: helping reduce costs for NGOs and ensuring people in the third world received lifesaving soap.

\section{Conclusion}

The Clean the World's new business model links profit- to social-value opportunities through the application of effectual entrepreneurship. As this paper highlighted, not all social ventures are started by "heroes" motivated by solving social problems. Rather, entrepreneurs are more likely aligned with Adam Smith's heavily debated (1993, 2009) view that economic self-interest ultimately results in desirable social outcomes. The effectual process of questioning the status quo provided Clean the World with a framework for changing the existing system by redefining waste as resource. Its founders' identification of a means - waste as a resource - steered them toward exploiting contingencies that brought about the development of new markets, alliances, and cooperative strategies. As a result, they created a new system of generating both profit and environmental impact in the first world, and used this throughput to generate the same outcomes (profit and social impact) in the third world. We believe that this new business model, represented by Clean the World, is replicable through the application of effectual entrepreneurship. If more markets or social entrepreneurs begin to view waste as a resource and - through the effectuation process - identify previously unobserved contingencies, which link profit- and social value opportunities, new economic opportunities would be created in conjunction with solving some of the most fundamental social problems of the twenty-first century (e.g., disease prevention through soap distribution).

Given that the field of economics is often perceived as being subject to Planglossian tendencies - too quick to make excuses for apparently dysfunctional aspects of the status quo and eager to question, dismiss, and criticize possible proposals to improve the status quo (Yunker 2009) - the study of effectual entrepreneurship, in conjunction with social entrepreneurship, can perhaps shift this predisposition. Instead of discouraging innovation based on the risk of being ridiculed, we should be fostering a cultural space where entrepreneurial creativity, alertness, and effectuation provides new, plausible proposals to reform and improve the status quo. For instance, as in the case of Clean the World, we can challenge entrepreneurs to identify existing but yet unseen possibilities by exploring economic production and consumption of society's throughput - resource and waste and by asking the question: How can I turn waste into a resource to make profit? 


\section{References}

Clean the World. Available at www.cleantheworld.org. Accessed April 10, 2013.

Braun, Justin and Barry Glenn. "Clean Sweep." Orlando Magazine, December 2013, www.orlandomagazine.com/Orlando-Magazine/December-2013/Clean-Sweep/.

Dale, Gareth. "Adam Smith's Green Thumb and Malthus's Three Horsemen: Cautionary Talesfrom Classical Political Economy." Journal of Economic Issues 46, 4 (2012): 859-880.

Dacin, Tina, Peter A. Dacin and Paul Tracey. "Social Entrepreneurship: A Critique and FutureDirections.” Organizational Science 22, 5 (2011): 1203-1213.

Gaglio, Connie Marie and Jerome A. Katz. "The Psychological Basis of Opportunity Identification: Entrepreneurial Alertness.” Small Business Economics 16, 2 (2001): 95-111.

Gimmon, Eli and Jonathan Levie. "Instrumental Value Theory and the Human Capital of Entrepreneurs." Journal of Economic Issues 43, 3 (2009): 715-732.

Klein, Philip A. "Changing Perspectives on the Factors of Production." Journal of Economic Issues 22, 3 (1988): 795-809.

Kirzner, Israel M. Competition and Entrepreneurship. Chicago: University of Chicago Press, 1973.

—. "Creativity and/or Alertness: A Reconsideration of the Schumpeterian Entrepreneur." Review of Economics 11, 1-2 (1999): 5-17.

—. "The Alert and Creative Entrepreneur: A Clarification." Small Business Economics 32, 2 (2009):145-152.

London, Manuel. "Leadership and Advocacy: Dual Roles for Corporate Social Responsibility and Social Entrepreneurship.” Organizational Dynamics 37, 4 (2008): 313-326.

Mair, Johanna and Ignasi Marti. "Social Entrepreneurship Research: A Source of Explanation, Prediction, and Delight." J. World Bus 41, 1 (2006) 36-44.

McDaniel, Bruce A. "Institutional Destruction of Entrepreneurship Through Capitalist Transformation." Journal of Economic Issues 37, 2 (2003): 495-501.

- "A Contemporary View of Joseph A. Schumpeter's Theory of the Entrepreneur." Journal of Economic Issues 39, 2 (2005): 485-489.

Sarasvathy, Saras D. "Causation and Effectuation: Toward a Theoretical Shift from Economic Inevitability to Entrepreneurial Contingency.” Academy of Management Review 26, 2 (2001): 243-263.

Schumpeter, Joseph A. The Theory of Economic Development. Cambridge, MA: Harvard University Press, 1934.

—. Capitalism, Socialism and Democracy. London: George Allen \& Unwin, 1943.

Smith, Adam. An Inquiry into the Nature and Causes of the Wealth of Nations. Oxford: Oxford University Press, [1776] 1993.

Santich, Kate. "After 10 Million Bars of Soap, Clean the World Is Just Beginning." Orlando Sentinel, January 15, 2012.

- The Theory of Moral Sentiments. Harmondsworth, England: Penguin, [1790] 2009.

Till, Paul. Co-Founder of Clean the World. Lecture Rollins College, Florida, April 11, 2013

Van den Bergh, Jeroen CJM, and Giorgos Kallis. "Growth, A-Growth or Degrowth to Stay Within Planetary Boundaries?” Journal of Economic Issues 46, 4 (2012): 909-920. 
Warnecke, Tonia. "Entrepreneurship and Gender: An Institutional Perspective." Journal of Economic Issues 42, 2 (2013): 455-463.

Yunker, James A. "Panglossian Tendencies in Economics: The Case of Theoretical Welfare Economics." Journal of Economic Issues 43, 3 (2009): 759-778. 